\title{
Building Customers' Re-Patronage Intention through Service Quality of Community Mall in Bangkok
}

\author{
Supeecha Panichpathom
}

\section{A B S T R A C T}

Objective: The main goal of the article is to propose a new framework exhibiting relationship between tangible dimension and all other intangible dimensions of SERVQUAL used to analyse the relation to re-patronage intention.

Research Design \& Methods: Hypothesised relationships were tested on data which was collected in Bangkok area using a survey questionnaire. Final sample consisted of 225 respondents, frequent visitors of community malls. The data was analysed using exploratory factor analysis as well as simple and multiple regression analysis. The six constructs, studied in this paper, were examined for differences in means across all demographic variables by employing analysis of variance or ANOVA.

Findings: The results exposed that tangible dimension had significant correlation to reliability, empathy, responsiveness and assurance dimensions consecutively. Multiple regression analysis demonstrated that re-patronage intention was explained by empathy, responsiveness and assurance dimensions, not reliability dimension. The ANOVA tests showed no significant differences in means of general data and all other constructs.

Implications \& Recommendations: To make shoppers to come back to the malls, managers should recognize the important role of tangible items as an antecedent to intangible items. Retail developers could devote more efforts to maximize the attractiveness of tangible elements and identify the weak areas of service quality by examining the multi-item constructs used to measure service quality.

Contribution \& Value Added: This study proposed and tested a modified conceptual model adapted from that proposed by Reimer and Kuehn (2005).

Article type: research paper

Keywords: $\quad$ service quality; community mall; re-patronage intention; SERVQUAL JEL codes: $\quad$ M31, O18, R2

Received: 28 September $2015 \quad$ Revised: 5 January $2016 \quad$ Accepted: 18 January 2016

\section{Suggested citation:}

Panichpathom, S. (2016). Building Customers' Re-Patronage Intention through Service Quality of Community Mall in Bangkok. Entrepreneurial Business and Economics Review, 4(2), 9-25, DOI: http://dx.doi.org/10.15678/EBER.2016.040202 


\section{INTRODUCTION}

In this study, community mall is understood as a neighbourhood shopping centre with open spaces in front of the centre and has at most three storeys. According to Colliers International Thailand report, in 2014 and 2015 community shopping malls would expand to serve residential projects growing around Bangkok area, capital city of Thailand (Kongcheep, 2014). Competition among retail developers has been more fiercely and managing community malls is also more challenging. New shopping channel such as mobile retailing or e-commerce market in Thailand in 2014 is a growing trend in retail business (Pitchon, 2015). Retailers, however, could utilize physical attributes of mortar and brick malls by providing relaxing and hangout atmosphere with convenient access to the malls. Some existing community malls have not operated successfully and have to implement a strategy to draw more customers and keep customers.

One strategy is to supply customers with high level of service quality in order to reduce cost of acquiring new customers, enhance customers satisfaction and loyalty and improve business performance (e.g., Cronin \& Taylor, 1992; Kim, \& Jin, 2002; Sureshchander, Rajendran, \& Anatharaman, 2002).

Parasuraman, Zeithaml and Berry (1985) have developed a measuring tool to measure service quality called SERVQUAL, consisting of ten dimensions. Later on, Parasuraman et al. (1988) have refined their tool and came up with 22 items and five service quality dimensions known as tangibles, reliability, empathy, responsiveness and assurance. Their further study in year 1994 reduced the original items to 21 items and suggests a simultaneous evaluation of both expectations and performance of service quality. Many empirical studies have applied SERVQUAL, as defined by Parasuraman et al. (1988) or with some modifications, across varied retail settings such as in fast food (Cronin \& Taylor, 1992), in discount and department stores (Finn \& Lamb, 1991), in dental school and tire store (Carman, 1990), utility company, brokerage company and banks (Parasuraman et al., 1985, 1988).

Some scholars have applied Retail Service Quality Scale (RSQS) to study quality of service in a retail sector. Dabholkar, Thorpe and Rentz (1996) developed RSQS and suggested hierarchical structure of five dimensions known as physical aspects, reliability, personal interaction, problem solving and policy. RSQS has been used to replicate the study in a retail sector such as in supermarket (Mehta, Lalwani, \& Han, 2000), in department store chain (Siu \& Cheung, 2001) and in discount stores (Kim \& Jin, 2002) and concluded that it was suitable for setting with less services, and rather more goods like in hypermarket.

Findings as to the direct and indirect influences of service quality perception on behaviour intention are numerous (e.g. Dagger, Sweeney \& Johnson, 2007; Ladhari, 2009; and Hooper, Coughlan, \& Mullen, 2013), nevertheless, this paper supplements the insights by investigating each dimensions of service quality on re-patronage intention, which is considered as one important variable in marketing literature.

The main objective of this study is to build a better understanding of the determinants of customers' re-patronage intention by modifying the structure of SERVQUAL instruments and empirically testing this proposed conceptual framework in context of community malls in Bangkok. It is hoped that community malls operators or developers will have 
insights as to how prioritize and improve service quality which will eventually generate positive re-patronage behaviour.

The remainder of this paper is organized as follows. Following the introduction is a review of service quality and re-patronage literature, which sets the foundation for the conceptual framework with tangibles as a predecessor of service quality perceptions. Next is research methodology and the last three more sections are results of empirical study and discussions; conclusions and implications of the findings followed by limitations and future research directions.

\section{LITERATURE REVIEW AND THEORY DEVELOPMENT}

\section{Service Quality}

Kang and James (2004) recommend scholars to pay more concentration on dimensions of service quality. Rather than adopting the American perspective, namely SERVQUAL model, they suggest researchers to investigate the European perspective, namely Gronroos' model, which consists of three dimensions (rather than five dimensions as of SERVQUAL) termed technical, functional and image quality.

Asubonteng, McCleary and Swan (1996) gather prior works as to dimensionality of service quality and conclude that the dimensionality from using SERVQUAL is mixed and it is not consistent across studies. Similarly, Brady and Cronin (2001) gather prior works and conclude that there is no agreement on dimensionality of service quality.

Numerous scholars have devoted their efforts to study the structure and dimensions of service quality, however, the results are not unanimous. In this paper, two approaches of measuring quality of service are studied. One is SERVQUAL developed by Parasuraman et al. and the other is Gronroos model. These two approaches complement each other.

Measuring quality has taken place in goods contexts with the hope to reach zero defects or no failure. This measurement concept could not be applied to service sectors due to their intangibility nature of service, heterogeneity of service, perishability of service and inseparability of production and consumption, (Parasuraman et al., 1985; Ghobadian, Speller \& Jones, 1994). In 1985, Parasuraman and colleagues undermine the importance of evaluating service quality in terms of both outcome and process of service delivery. This suggestion is consistent with the model proposed by Gronroos $(1984,1994)$. Gronroos $(1984,1994)$ claims that there are two types of service quality, namely, technical quality (which was the outcome of service or the actual services received) and functional quality (which was the process of service or the mean to deliver services). This Tangibles dimension of SERVQUAL is adopted as technical quality which could be evaluated objectively. Furthermore, Nisco and Warnaby, (2013) highlight that numerous prior scholars have conducted empirical studies and found that tangible dimension of original SERVQUAL affects service quality perception. For example, Reimer and Kuehn (2005) have proposed a model illustrating Tangibles as an antecedent of other intangible dimensions. Reason to separate tangible construct from the rest constructs of SERVQUAL is due to the nature of tangible that allows customer to perceive about other intangible dimension. For instance, the neat appearance of employees at food and beverage stores in a community mall might make customers assume to receive appropriate care from employees. 
The original SERVQUAL tool has divided service quality into two main clusters, or tangible and intangible clusters. One construct designated as Tangibles consists of appearances of physical facilities and personnel. Intangible clusters are comprised of four constructs known as empathy, responsiveness, assurance and reliability. The operationalization of these four constructs is as follows. Empathy refers to the ability to provide customers with appropriate attention and information and also convenient opening hours. Responsiveness is the willingness to help and provide prompt products/services to customers. Assurance describes the ability to ensure customers with confidence, knowledge and trust. Reliability is reflected as the ability to perform service dependably and effectively.

In seminal work of Parasuraman and colleagues originally suggests measurement of the quality of service by comparing the expectations with performance of service delivered to customers. However, prior scholars have adopted different dimensions of service quality. Customers shopping at community malls spend more time in malls and sense the appearances of physical facilities and personnel or staff before making purchase decision. These appearances are tangibles and should be a predecessor to service quality perception. This perspective is consistent with prior studies.

In this study, author groups all five dimensions of SERVQUAL into three clusters, i.e., Tangibles cluster as an antecedent; Interaction cluster, composing of empathy, responsiveness and assurance dimensions, and the last cluster is Reliability. In fact, both interaction and reliability cluster are intangible quality. However, the separation reliability dimension from other intangible dimensions corresponds to the work of Dabholkar et al. (1996), which have grouped service quality into three clusters and their findings have reflected that their proposed model is more effective when managers wanted to diagnose the problem areas in service quality.

\section{Re-patronage Intention}

In this study, re-patronage intention is the likelihood to revisit or continue shopping at the same community mall. Howat, Crilley and McGrath (2008) have emphasized that re-patronage intention variable is worth to understand because it is a powerful tool for managing service quality. They also undermined that re-patronage intention is a subset of loyalty construct. Two views of loyalty are behaviour view (including repurchase) and attitudinal view. Re-patronage intention is an attitudinal view of loyalty construct. Lasorn and Kananurak (2012) concentrated on the relation between service quality and loyalty, which is one form of re-patronage, but with customer satisfaction as a mediator. This study intends to investigate direct relation between service quality dimensions and re-patronage without any mediators.

\section{Conceptual Framework Development \& Hypotheses Tests}

Based on prior research studies included in the literature review, the author developed a conceptual framework as shown in Figure 1. 


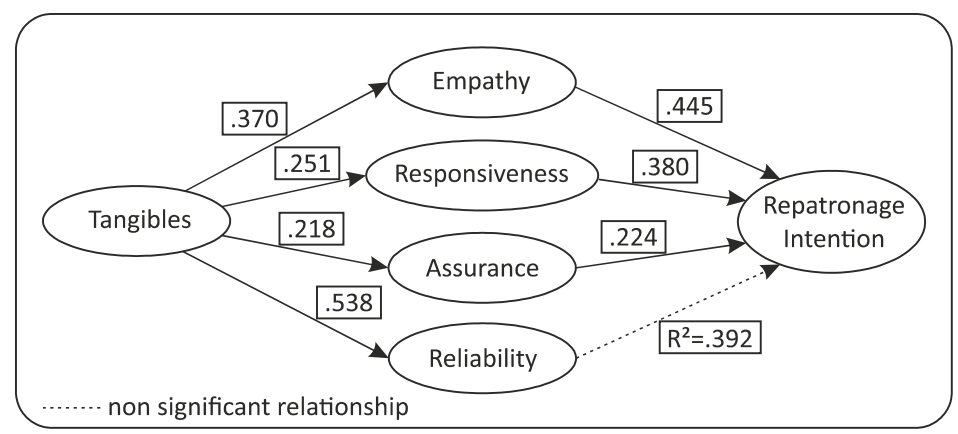

Figure 1. Conceptual Framework of this study

Source: own study.

From the above discussion and framework, the following hypotheses were developed:

H1a: Tangibles are positively related to empathy.

H1b: Tangibles are positively related to responsiveness.

H1c: Tangibles are positively related to assurance.

H1d: Tangibles are positively related to reliability.

H2a: Empathy is positively related to re-patronage intention.

H2b: Responsiveness is positively related to re-patronage intention.

H2c: Assurance is positively related to re-patronage intention.

H2d: Reliability is positively related to re-patronage intention.

\section{MATERIAL AND METHODS}

\section{Sampling \& Data Collection}

This study employed structured questionnaires and distributed via Google Doc during

Table 1. Number of Respondents Classified by Most Frequently Visits Community Malls

\begin{tabular}{|l|c|}
\hline \multicolumn{1}{|c|}{ Community Mall } & Number of Respondents \\
\hline Major Avenue, Ratchayothin & 77 \\
\hline La Villa, Ari & 41 \\
\hline The Crystal @ Crystal Park & 28 \\
\hline J Avenue, Thonglor & 26 \\
\hline The Circle, Ratchapruk & 23 \\
\hline Navamin City Avenue, Navamin & 23 \\
\hline K Village, Sukhumvit 26 & 12 \\
\hline The Nine, Rama IX & 10 \\
\hline \multicolumn{2}{|c|}{} \\
\hline The Paseo, Ladkrabang & 8 \\
\hline Porto Chino, Rama II & 4 \\
\hline Rain Hill, Sukhumvit 47 & 2 \\
\hline Park Lane, Sukhumvit 61 & 1 \\
\hline
\end{tabular}

Source: own study. 
the year 2014. The number of valid questionnaires was 255. Data given by respondents, who are based on the community malls that they most frequently visit during past one year. The list of these malls and the number of all 255 respondents for each mall is shown in Table 1.

\section{Measurement Instruments}

The developed measurement items for all five dimensions of SERVQUAL was initially based on original tool generated by Parasuraman et al. (1998), and also borrowed items from prior studies (Table 2 ) and adapted them to fit the community mall environment.

Table 2. Measurement Items Used in Questionnaire

\begin{tabular}{|c|c|}
\hline CONSTRUCT/ITEMS & SOURCE \\
\hline \multicolumn{2}{|l|}{ TANGIBLES } \\
\hline 1. Buildings and physical facilities have a modern looking. & $1,3,5,7,8,11,12,16,17,18,22$ \\
\hline 2. Buildings and physical facilities look clean. & $8,9,10,11,19,21,22$ \\
\hline 3. External appearance of buildings is visually attractive. & $1,2,3,5,6,7,8,10,11,12,13,17,22$ \\
\hline 4. Employees are well dressed and neat. & $1,2,5,7,9,10,12,14,15,16,17,18$ \\
\hline 5. The arrangement of tenants in this mall eases me to get to needed stores. & $3,8,20$ \\
\hline 6. The arrangement of passages in this mall eases me to move around. & $3,8,9,18,20,21$ \\
\hline \multicolumn{2}{|l|}{ RELIABILITY } \\
\hline 1. Employees are dependable in giving me services. & $7,17,18$ \\
\hline 2. Employees maintain integrity and completeness of my records. & $2,3,5,7,8,11,17,18$ \\
\hline 3. Employees provide meticulous services to me. & $7,12,19$ \\
\hline 4. Employees perform effective problem solving when I have problems. & $1,2,3,12$ \\
\hline \multicolumn{2}{|l|}{ RESPONSIVENESS } \\
\hline 1. Employees are willing to help me promptly to get needed products/services. & $1,5,7,8,9,10,11,12,16,17,19$ \\
\hline 2. Employees are easy to be reached. & $1,5,7,16,22$ \\
\hline \multicolumn{2}{|l|}{ RESPONSIVENESS } \\
\hline 3. Employees have ability to promptly provide products/services to me. & $3,9,11,12$ \\
\hline 4. Employees are always willing to help me. & 1,18 \\
\hline \multicolumn{2}{|l|}{ ASSURANCE } \\
\hline 1. Employees have knowledge to answer my questions. & $1,3,5,7,11$ \\
\hline 2. Behaviours of employees instil my confidence. & $1,3,5,7$ \\
\hline 3. Employees are consistently courteous with me. & $1,5,7,11,18$ \\
\hline 4. Customers feel safe in doing transaction with employees. & $1,3,5,7,11,17$ \\
\hline \multicolumn{2}{|l|}{ EMPATHY } \\
\hline 1. Employees have ability to communicate clearly to me. & 19 \\
\hline 2. Employees make friendly impression on me. & 18 \\
\hline 3. Employees understand individual needs of me. & $1,5,15,18$ \\
\hline 4. Employees give me individual attention. & $1,3,5,7,11,15,18$ \\
\hline 5. Opening hours of this mall are convenient to me. & $1,3,5,7,15,17,18$ \\
\hline 6. Employees have my best needs at heart. & $7,11,15,17$ \\
\hline \multicolumn{2}{|l|}{ RE-PATRONAGE INTENTION } \\
\hline 1. I will recommend my friends or acquaintances to have shopping at this mall. & $6,10,13,22$ \\
\hline 2. In the future, I will come back to this mall. & 13,22 \\
\hline 3. I will continue have shopping at this mall. & 4 \\
\hline 4.It is very likely for me to shop at this mall again. & 4 \\
\hline
\end{tabular}

Notes: 1 Bebko, 2000; 2 Cronin \& Taylor, 1992; 3 Dabholkar, Thorpe \& Rentz, 1996; 4 Dagger, Sweeney \& Johnson, 2007; 5 Harmse, 2014; 6 Hooper, Coughlan \& Mullen, 2013; 7 Kang \& James, 2004; 8 Khare, 2013; 9 Kitchareon, 2004; 10 Ladhari, 2009; 11 Lonial, Menezes, Tarim, Tatoglu \& Zaim, 2010; 12 Markovic \& Raspor, 2010; 13 Nisco \& Warnaby, 2013

Source: own study. 
The questionnaire consisted of three sections. The first one had only one filter question to ensure that respondents were customers who shop at any community mall in Bangkok at least one time during the past one year. Second section, with the instruction to ask respondents to think of one community mall that he/she frequently shopped, was meant to measure all six constructs. All measurement items were five-point Likert scale ranging from 1 (strongly disagreement) to 5 (strongly agreement). The last section was demographic data including gender, age, marital status, level of education, occupation, and individual and household income per month. The questionnaire was pre-tested with $30 \mathrm{sam}$ ples and was modified for clarity.

To test the suitability of data for factor analysis, this study performed the KaiserMeyer-Olkin (KMO) for sampling adequacy and Bartlett's test for sphericity. The reliability tests with coefficient alpha or Cronbach alpha values were computed for all 26 items. The item reduction and scale purification were investigated with criteria of items with low factor loadings (<.5), communalities and low-item-to-total correlations. This process was rerun many times until no more improvement to the Cronbach alpha values and had clear factor dimensions.

\section{Data Analysis}

Due to the instability of SERVQUAL dimensions and structure, the use of exploratory factor analysis, simple and multiple regression analysis and ANOVA could be more appropriate techniques than structure equations model. The descriptive statistics and inferential statistics used to test hypotheses were conducted by SPSS software 18 version. Hypotheses $1 \mathrm{a}$ to hypotheses $1 \mathrm{~d}$ was tested with simple regression analysis and hypotheses $2 \mathrm{a}$ to hypotheses $2 \mathrm{~d}$ were tested with multiple regression analysis.

An exploratory factor analysis with principal components analysis and varimax rotation were performed to examine the dimensionality of interaction cluster of service quality and to minimize the number of variables. The criteria in determining number of factors were an eigenvalue greater than 1 and cumulative percentage of variance explained greater than 50 percent.

The six constructs, studied in this paper, were examined for differences in means across all demographic variables by employing analysis of variance or ANOVA.

\section{RESULTS AND DISCUSSION}

\section{Descriptive Statistics \& Reliability Test}

Table 3 presents the mean and standard deviation for all measurement items (22 items for all five dimensions of service quality and four items of re-patronage intention construct). Mean scores of all variables with five-point scale were in the range of 3.690 to 4.259 which was moderate high and standard deviations were in the range of 0.605 to 0.941 which was quite low.

The characteristics of respondents were as follows. Majority of respondents were female $(63 \%)$ and were single (84.7\%). Most of the respondents were aged $20-29(56.5 \%)$ and $30-39(31.8 \%)$ respectively, with $59.2 \%$ completed bachelor's degree and $32.9 \%$ earned higher than bachelor's degree. Majority of respondents did not work in public sector, with $42 \%$ were officers in private sectors and $28.2 \%$ were freelance or entrepreneurs. The individual income per month was between Baht 10,000-30,000 (57.2\%), and 
Table 3. Exploratory Factor Analysis Results and Reliability Tests

\begin{tabular}{|c|c|c|c|c|}
\hline Constructs and Items & $\begin{array}{l}\text { Factor } \\
\text { Loading }\end{array}$ & $\begin{array}{l}\text { Communal } \\
\text { Extraction }\end{array}$ & Mean & S.D. \\
\hline \multicolumn{5}{|l|}{ Tangibles } \\
\hline Buildings and physical facilities look clean. & & 0.574 & 4.141 & 0.605 \\
\hline Buildings and physical facilities have a modern looking. & & 0.570 & 4.016 & 0.634 \\
\hline External appearance of buildings is visually attractive. & & 0.559 & 3.898 & 0.632 \\
\hline Employees are well dressed and neat. & & 0.471 & 3.957 & 0.666 \\
\hline$\%$ of Variance Explained $=54.322$ & & & & \\
\hline KMO \& Bartlett's Test $=0.729 \& 189.78$ & & & & \\
\hline \multicolumn{5}{|l|}{ Reliability } \\
\hline Employees provide meticulous services to me. & & 0.801 & 3.973 & 0.801 \\
\hline Employees maintain integrity and completeness of my records. & & 0.656 & 3.820 & 0.788 \\
\hline Employees are dependable in giving me services. & & 0.616 & 3.961 & 0.657 \\
\hline Employees perform effective problem solving when I have problems. & & 0.609 & 4.090 & 0.745 \\
\hline$\%$ of Variance Explained $=67.057$ & & & & \\
\hline KMO \& Bartlett's Test $=0.780 \& 405.85$ & & & & \\
\hline \multicolumn{5}{|l|}{ Empathy } \\
\hline Employees make friendly impression on me. & 0.818 & & 4.035 & 0.825 \\
\hline Employees give me individual attention. & 0.804 & & 4.012 & 0.835 \\
\hline Employees have ability to communicate clearly to me. & 0.798 & & 3.957 & 0.780 \\
\hline Employees have my best needs at heart. & 0.762 & & 3.847 & 0.825 \\
\hline Employees understand individual needs of me. & 0.698 & & 3.871 & 0.810 \\
\hline Opening hours of this mall are convenient to me. & 0.686 & & 4.259 & 0.673 \\
\hline \begin{tabular}{|ll}
$\%$ of Variance Explained $=59.161$ & Eigenvalues $=8.283$ \\
KMO \& Bartlett's Test $=0.887 \& 0.00114$ & Cronbach $\propto=0.818$
\end{tabular} & & & & \\
\hline \multicolumn{5}{|l|}{ Responsiveness } \\
\hline Employees are easy to be reached. & 0.847 & & 3.773 & 0.911 \\
\hline Employees have ability to promptly provide products/services to me. & 0.840 & & 3.839 & 0.780 \\
\hline $\begin{array}{l}\text { Employees are willing to help me promptly to get needed products/ser- } \\
\text { vices. }\end{array}$ & 0.756 & & 3.910 & 0.941 \\
\hline Employees are always willing to help me. & 0.700 & & 3.933 & 0.896 \\
\hline \begin{tabular}{|ll}
$\%$ of Variance Explained $=8.927$ & Eigenvalues $=1.250$ \\
KMO \& Bartlett's Test $=0.825 \& 691.36$ & Cronbach $\propto=0.834$ \\
\end{tabular} & & & & \\
\hline \multicolumn{5}{|l|}{ Assurance } \\
\hline Customers feel safe in doing transaction with employees. & 0.857 & & 4.086 & 0.705 \\
\hline Employees are consistently courteous with me. & 0.791 & & 4.098 & 0.765 \\
\hline Behaviors of employees instil my confidence. & 0.789 & & 3.839 & 0.764 \\
\hline Employees have knowledge to answer my questions. & 0.716 & & 3.902 & 0.848 \\
\hline$\%$ of Variance Explained $=8.371$ & & & & \\
\hline KMO \& Bartlett's Test $=0.840 \& 671.99$ & & & & \\
\hline \multicolumn{5}{|l|}{ Re-patronage Intention } \\
\hline $\begin{array}{l}\text { I will recommend my friends or acquaintances to have shopping at this } \\
\text { mall. }\end{array}$ & & 0.856 & 3.920 & 0.668 \\
\hline It is very likely for me to shop at this mall again. & & 0.811 & 4.020 & 0.763 \\
\hline I will continue have shopping at this mall. & & 0.689 & 3.690 & 0.857 \\
\hline In the future, I will come back to this mall. & & 0.679 & 4.100 & 0.648 \\
\hline$\%$ of Variance Explained $=75.879$ & & & & \\
\hline KMO \& Bartlett's Test $=0.812 \& 633.91 \quad$ Cronbach $\propto=0.887$ & & & & \\
\hline
\end{tabular}

Method of extraction: principal component with varimax rotation. Not include variables with factor loadings $<0.50$ in the analysis.

Source: own study. 
greater than Baht 50,000 (17.3\%) respectively while household income per month was at least Baht 100,001 (49\%), and between Baht 50,000-100,000 (39.6\%) respectively.

Table 3 presents Cronbach alpha values for three clusters of constructs, namely Tangibles dimension, Interaction dimension, which was comprised of empathy, responsiveness and assurance dimensions, and Reliability dimension. All six constructs had Cronbach alpha ranging from 0.718 to 0.887 , which were above 0.70 or standard value set by Nunnally (1978) and, therefore, considered good reliability. Also shown in Table 3 was the Cronbach alpha value $(0.887)$ of re-patronage intention construct above 0.70 .

\section{Exploratory Factor Analysis}

KMO measure for all six constructs were in the range of 0.729 to 0.887 and all Bartlett's tests were all significant $(p<0.000)$ with chi square values of 0.00114 to 691.36 (Table 3 ) reflecting correlation matrix was not identity matrix. KMO measure of interaction dimensions was 0.903 and chi square value of the Bertlett's test was 0.00313 at a significance level of 0.000 . This test indicated that correlation matrix was not an identity matrix.

Three constructs (grouped into interaction dimensions), namely empathy, responsiveness and assurance, were extracted from 14 items (Table 3 ) and it accounted for $76.459 \%$ of variance which illustrated satisfactory constructs. The eigenvalue as to three constructs ranged from 1.172 to 8.283 , which all were above 1 . Communality extraction column of Table 3 also reflected the overall significance of these constructs.

In sum, the antecedent of service quality perception is Tangibles construct. The mean scores of four items are in the range of 3.898 to 4.141 . The lowest mean score is on the attractiveness of buildings.

Empathy dimension is the most important dimension among the second cluster of service quality or dimensions of interaction quality. It is accounted for $59.161 \%$ of the total variance and an eigenvalue of 8.283. This dimension focuses on individualized attention and convenient working hours. The highest loading is for receiving friendly impression from employees. According to mean scores of this dimension, the weak areas are on understanding customers' needs and individualized needs and clearly communication to customers. The second significant dimension is responsiveness dimension, which explains $8.927 \%$ of total variance and has an eigenvalue of 1.250 . The highest loading is for item "ease of contact to employees" and this item has lowest mean score. The last dimension of interaction dimensions is assurance dimension, which explains $8.371 \%$ of total variance and has an eigenvalue of 1.172. The lowest mean score for this dimension is on item "behaviours of employees instil my confidence" and the highest loading is for item "customers feel safe in doing transaction with employees".

The last cluster of service quality dimensions is Reliability construct. The mean scores of four items are between 3.82 and 4.09. This dimension received quite low scores on each item comparing to other dimension.

\section{Assumptions Checks for Multiple Regression Analysis}

The assumptions of multiple regression analysis, which are linearity, homoscedasticity or homogeneity of variance, normality are tested. Moreover, the multicollinearity and outliers are checked. The scatter plot of the residuals against the predicted values (Figure 2) does not show any pattern, thus, visually shows that linearity and homoscedasticity assumptions are met. 
Scatterplot

Dependent Variable: Factor Scores of Repatronage Intention

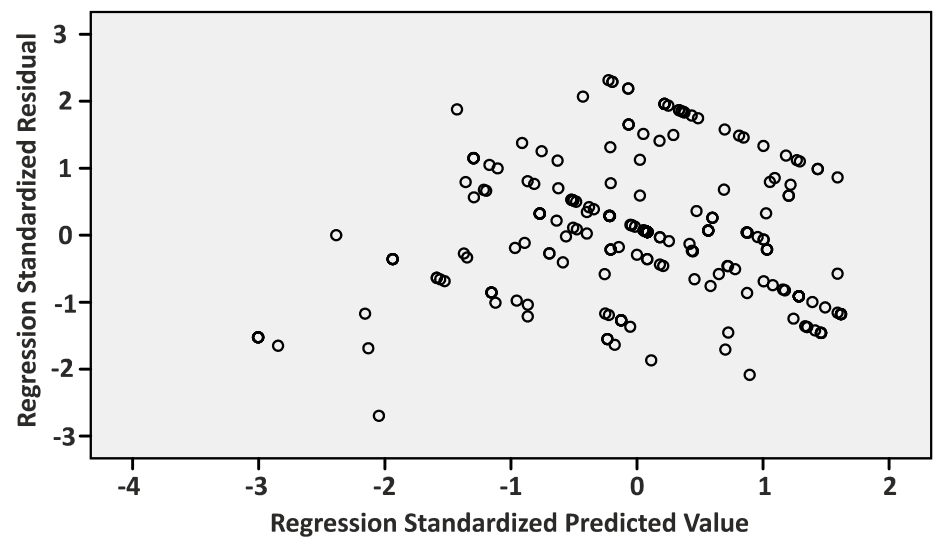

Figure 2. Scatterplot Showing a Relationship with Standardized Residuals Predicted Values Source: own study.

The histogram (Figure 3) and the normal p-p plot of residuals (Figure 4) visually demonstrate a normal distribution, thus, normality assumption is satisfied.

The measures of variance inflation factor or VIF of all independent variables (Table 4) are less than 10 and their Tolerance measures are greater than 0.1 , which indicate that there is no multicollinearity.

The results of standardized Dfbeta values shown in Table 5 are not less than -2 or greater than 2 so the conclusion is that there is no outliers or influential case in these data.

Histogram

Dependent Variable: Factor Scores of Repatronage Intention

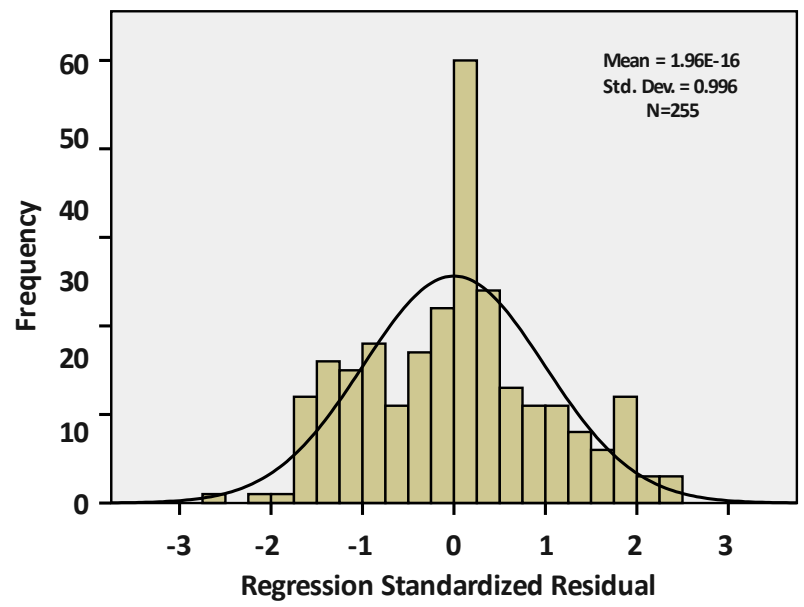

Figure 3. Histogram of Regression Standardized Residuals Source: own study. 
Normal P-P Plot Regression Standardized Residual Dependent Variable: Factor Scores of Repatronage Intention

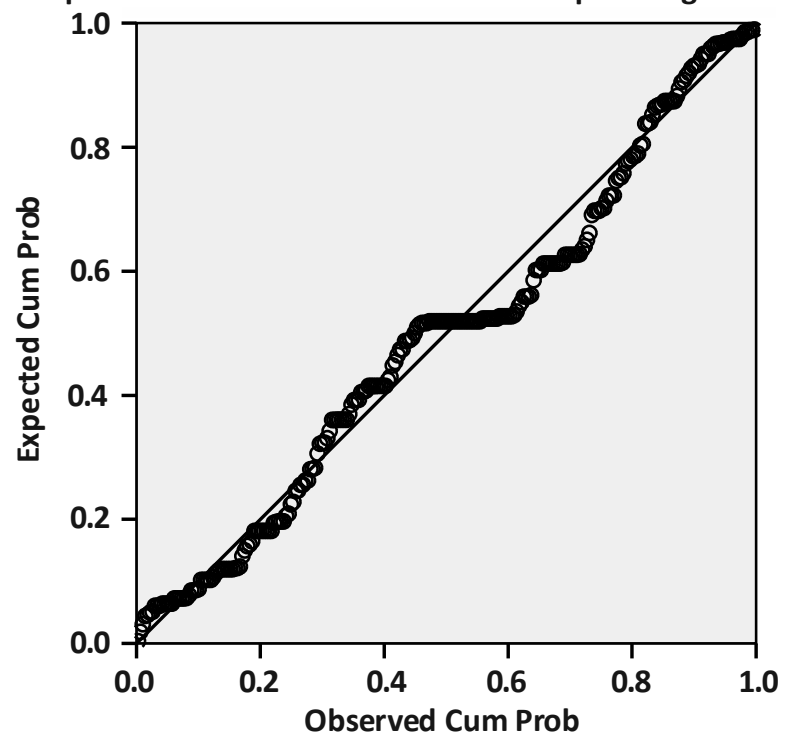

Figure 4. Histogram of Regression Standardized Residuals Source: own study.

Table 4. Coefficients Matrix with Collinearity Statistics: Coefficients ${ }^{\mathrm{a}, \mathrm{b}}$

\begin{tabular}{|c|c|c|c|c|c|c|c|c|}
\hline & \multicolumn{2}{|c|}{$\begin{array}{c}\text { Unstandardized Co- } \\
\text { efficients }\end{array}$} & \multirow{2}{*}{\begin{tabular}{|c|}
$\begin{array}{c}\text { Standardized } \\
\text { Coefficients }\end{array}$ \\
Beta \\
\end{tabular}} & \multirow{2}{*}{$\mathbf{t}$} & \multirow{2}{*}{ Sig. } & \multicolumn{2}{|c|}{ Collinearity Statistics } \\
\hline & & B & Std. Error & & & & Tolerance & VIF \\
\hline \multirow{3}{*}{1} & Empower & .445 & .049 & .445 & 9.057 & .000 & 1.000 & 1.000 \\
\hline & Responsiveness & .380 & .049 & .380 & 7.727 & .000 & 1.000 & 1.000 \\
\hline & Assurance & .224 & .049 & .224 & 4.555 & .000 & 1.000 & 1.000 \\
\hline
\end{tabular}

a. Dependent Variable: Re-patronage Intention

b. Linear Regression through the Origin

Source: own study.

Table 5. The Maximum and Minimum Values of Standardized DfBetas: Descriptive Statistics

\begin{tabular}{|l|r|r|r|r|r|}
\hline \multicolumn{1}{|c|}{ Standardized DfBetas } & N & Minimum & Maximum & \multicolumn{1}{c|}{ Mean } & $\begin{array}{c}\text { Std. } \\
\text { Deviation }\end{array}$ \\
\hline SDB1_1 Standardized DFBETA empower & 255 & -.20484 & .33091 & .0002700 & .07803365 \\
\hline SDB2_1 Standardized DFBETA responsivenss & 255 & -.30443 & .37962 & .0001050 & .07416826 \\
\hline SDB3_1 Standardized DFBETA assurance & 255 & -.20384 & .29544 & .0001122 & .06449681 \\
\hline SDB0_1 Standardized DFBETA Intercept & 0 & & & & \\
\hline Valid N (listwise) & 255 & & & & \\
\hline
\end{tabular}

Source: own study.

In sum, all assumptions of multiple regression analysis are not violated. 


\section{Simple and Multiple Regression Analysis}

This study performed simple regression analysis to test relationships between Tangibles and the rest of four construct of SERVQUAL dimensions, which is the hypothesis 1a to hypothesis $1 \mathrm{~d}$. All hypothesis $1 \mathrm{a}$ to hypothesis $1 \mathrm{~d}$ were supported and regression coefficient at 0.01 level of empathy, responsiveness, assurance are reliability were $0.370,0.251,0.218$ and 0.538 respectively (Figure 1 ). The influences of Tangibles construct is on dimensions reliability (0.538), empathy $(0.37)$, responsiveness $(0.251)$ and assurance $(0.218)$ respectively.

Multiple regression analysis was performed to test the relationship between the interaction dimensions of service quality and re-patronage intention. Table 6 indicated the value of $R$ equalled to 0.629 meaning positive and moderate strong relationship between independent variables, which were empathy, responsiveness and assurance, and dependent variable, which was re-patronage intention. The coefficient of multiple determinations or $\mathrm{R}^{2}$ was 0.395 or $39.5 \%$ of variation in re-patronage intention was explained by all independent variables (Table 7). In Table 7, the F-value score was 40.994 with $p$-value 0.000 , which illustrated that there was a significant difference between dependent variable and independent variables. Table 7 showed that only three independent variables, which were empathy, responsiveness and assurance, were significant and influential in the re-patronage intention. The regression equation shown in Table 8 was Re-patronage Intention $=0.466$ (empathy) +0.395 (responsiveness) +0.239 (assurance). Since reliability was not significant, the author performed multiple regression analysis without reliability construct. The new results were slightly different from the old ones. The new regression equation was Re-patronage Intention $=0.445$ (empathy) +0.380 (responsiveness) +0.224 (assurance) with $R$ value of 0.626 and $R^{2}$ of 0.392 . In sum, customers evaluated the quality

Table 6. Multiple Regression Analysis Summary for Re-patronage Intention: Model Summary

\begin{tabular}{|l|l|l|l|l|}
\hline Model & $\mathrm{R}$ & R Square $^{\mathrm{b}}$ & Adjusted R Square & Std. Error of the Estimate \\
\hline 1 & $.629^{\mathrm{a}}$ & .395 & .386 & .78235675 \\
\hline
\end{tabular}

a. Predictors: Assurance, Responsiveness, Empathy

b. For regression through the origin (the no-intercept model), R Square measures the proportion of the variability in the dependent variable about the origin explained by regression. This CANNOT be compared to R Square for models which include an intercept

Source: own study.

Table 7. Multiple Regression Analysis ANOVA for Re-patronage Intention: ANOVA ${ }^{c, d}$

\begin{tabular}{|l|l|l|l|l|l|l|}
\hline \multicolumn{2}{|l}{ Model } & Sum of Squares & df & Mean Square & F & Sig. \\
\hline \multirow{3}{*}{1} & Regression & 100.367 & 4 & 25.092 & 40.994 & $.000^{\mathrm{a}}$ \\
\cline { 2 - 8 } & Residual & 153.633 & 251 & .612 & & \\
\cline { 2 - 7 } & Total & $254.000^{\mathrm{b}}$ & 255 & & & \\
\hline
\end{tabular}

a. Predictors: Assurance, Responsiveness, Empathy

b. This total sum of squares is not corrected for the constant because the constant is zero for regression through the origin

c. Dependent Variable: Re-patronage Intention

d. Linear Regression through the Origin

Source: own study. 
of empathy, responsiveness and assurance when they decided whether to shop again at the same community mall.

Table 8. Multiple Regression Analysis Coefficients for Re-patronage Intention: Coefficients ${ }^{\mathrm{a}, \mathrm{b}}$

\begin{tabular}{|c|c|c|c|c|c|c|}
\hline \multirow{2}{*}{\multicolumn{2}{|c|}{ Model }} & \multicolumn{2}{|c|}{ Unstandardized Coefficients } & \multirow{3}{*}{$\begin{array}{l}\text { Standardized Coefficients } \\
\text { Beta } \\
466\end{array}$} & \multirow{3}{*}{$\begin{array}{c}\mathbf{t} \\
6.992 \\
\end{array}$} & \multirow{3}{*}{$\begin{array}{l}\text { Sig. } \\
.000\end{array}$} \\
\hline & & \multirow{2}{*}{$\begin{array}{l}\text { B } \\
466\end{array}$} & \multirow{2}{*}{$\begin{array}{r}\text { Std. Error } \\
.067\end{array}$} & & & \\
\hline \multirow{4}{*}{1} & Empathy & & & & & \\
\hline & Responsiveness & .395 & .059 & .395 & 6.682 & .000 \\
\hline & Assurance & .239 & .058 & .239 & 4.094 & .000 \\
\hline & Reliability & -.038 & .081 & -.038 & -.476 & .634 \\
\hline
\end{tabular}

a. Dependent Variable: Re-patronage Intention

b. Linear Regression through the Origin

Source: own study.

Reason explaining the insignificant relation of reliability construct to re-patronage intention might be the validity of this measurement items. When author group these items into interaction dimensions, there is no clear factor structure. Moreover, these items got quite low mean scores, which might be due to bias sampling.

\section{Analysis of Variance (ANOVA)}

The results from ANOVA were quite surprising because there were no significant differences shown in the statistics across all demographic variables. This might be due to the limited size of sample.

\section{CONCLUSIONS}

\section{Final Remarks and Implications}

The proposed framework of this study is consistent with concepts emphasizing tangible elements are main components of service quality (Parasuraman et al., 1988, 1991; Cronin \& Taylor, 1992).

This paper combined studies on service quality in the areas of measurement, structure and number of dimensions of service quality applied to community malls in Bangkok. The results of this empirical study supported the hypothesis that Tangibles construct is an antecedent of the other four constructs. One explanation is people shopped in community malls were hedonic motivated people (Dhurup, 2008) and wanted to spend more time in community mall for reasons other than product acquisition, such as socialization, recreation, convenient location and stores' attributes.

First of all, to make shoppers to come back to the malls, managers should recognize the important role of tangible items as an antecedent to intangible items. Retail developers could devote more efforts to maximize the attractiveness of tangible elements and identify the weak areas of service quality by examining the multi-item constructs used to measure service quality. From the above analysis and discussion, managers should pay attention to the following concerns.

From the findings as to tangible elements and due to the ability of customers to evaluate tangible elements objectively, retailers or community malls managers should set first priority on increasing the attractive design of building. As to empathy and responsiveness 
dimensions, managers should set training programs to help employees know their customers and leading to generate clearly communication and understandings of customers' needs. For the assurance dimension, managers might need to build the manner of their employees to be capable of addressing customers' transaction with confidence.

Results exposed three dimensions, i.e., empathy, responsiveness and assurance, are important predictors for customers' intention to return to community malls. However, the hypothesised relationship between reliability dimension and re-patronage intention was not significantly supported. In sum, building re-patronage intention in community malls need to emphasize the importance of Tangible elements that has the highest and significant relation to empathy dimension. Reliability dimension did not significantly relate to repatronage intention. When retailers have insights as to the structure and dimensionality of service quality, they could strengthen and differentiate the higher offerings to target customers.

\section{Limitations and Further Research}

Since Tangibles construct is significantly related to all intangible dimensions of service quality, which lead to re-patronage intention, future studies might concentrate on the moderator roles of four dimensions of intangible elements. Moreover, the findings from ANOVA indicated no differences in means across all demographic variable. These findings are contradict with many previous studies (e.g. Baker, Parasuraman, Grewal, \& Voss, 2002; El-Adly, 2007; Dhurup, 2008; and Gudonaviciene, \& Alijosiene, 2013). However, majority of the respondents of this study represent high educated-people with high household income. They might not be good representatives of community malls in Bangkok. Furthermore, the author distributed questionnaire through Google Doc, which might lead to selection bias. In future, scholars might try to gather data from people who just walk out of community malls, have varied background and try to increase the size of samples. The number of community malls that respondents most frequently visited during past one year is only 12 , which might not be a good representation of all community in Bangkok and suburban areas. However, it could represent the popular community malls. Moreover, since this study proposed new integrated framework and used Likert scale with exploratory factor analysis, researchers might use confirmatory factor analysis with better representative of samples to confirm the relationships found in this study. Lastly, researchers might perform comparative study applied both RSQS and a new structure of SERVQUAL as proposed in this study. The relative power of these two models might be more meaningful in setting marketing strategy for building re-patronage intention. 


\section{REFERENCES}

Asubonteng, P., McCleary, K., \& Swan, J. (1996). SERVQUAL revisited: a critical review of service quality. The Journal of Services Marketing, 10(6), 62-81.

Baker, J., Parasuraman, A., Grewal, D., \& Voss, G. (2002). The Influence of Multiple Store Environment Cues on Perceived Merchandise Value and Patronage Intentions. Journal of Marketing, $66,120-141$.

Bebko, C. (2000). Service intangibility and its impact on consumer expectations of service quality. Journal of Services Marketing, 14(1), 9-26.

Brady, M., \& Cronin, J. (2001). Some New Thoughts on Conceptualizing Perceived Service Quality: A Hierarchical Approach. Journal of Marketing, 65(3), 34-49.

Carman, M. (1990). Consumer perceptions of service quality: an assessment of the SERVQUAL dimensions. Journal of Retailing, 66(1), 33-55.

Cronin, J., \& Taylor, S. (1992). Measuring Service Quality: A Reexamination and Extension. Journal of Marketing, 56(3), 55-68.

Dabholkar, P., Thorpe, D., \& Rentz, J. (1996). A Measure of Service Quality for Retail Stores: Scale Development and Validation. Journal of the Academy of Marketing Science, 24(1), 3-16.

Dagger, T., Sweeney, J., \& Johnson, L. (2007). A Hierarchical Model of Health Service Quality. Journal of Services Research, 10(2), 123-142.

Dhurup, M. (2008). A Generic Taxonomy of Shopping Motives Among Hypermarkets Customers and the Relationship with Demographic Variables. Acta Commercii, 8(1), 64-79.

El-Adly, M. (2007). Shopping malls attractiveness: a segmentation approach. International Journal of Retail \& Distribution Management, 35(11), 936-950.

Finn, W., \& Lamb, W. (1991). An evaluation of the SERVQUAL scale in retail setting. Advances in Consumer Research, 18, 483-490.

Ghobadian, A., Speller, S., \& Jones, M. (1994). Service Quality: Concepts and Models. International Journal of Quality \& Reliability Management, 11(9), 43-66.

Gronroos, C. (1984). A Service Quality Model and its Marketing Implications. European Jouranl of Marketing, 18(4), 36-44.

Gronroos, C. (1994). From Scientific Management to Service Management: A Management Perspective for the Age of Service Competition. International Journal of Service Industry Management, $5(1), 5-20$.

Gudonaviciene, R., \& Alijosiene, S. (2013). Influence of Shopping Centre Image Attributes on Customer Choices. Economics and Management, 18(3), 545-552.

Harmse, C. (2014). Service quality in landlord-small business relationship in shopping centres. Problems and Perspectives in Management, 12(4), 67-77.

Hooper, D., Coughlan, J., \& Mullen, M. (2013). The servicescape as an antecedent to service quality and behavioral intentions. Journal of Servoces Marketing, 27(4), 271-280.

Howat, G., Crilley, G., \& McGrath, R. (2008). A focused service quality, benefits, overall satisfaction and loyalty model for public aquatic center. Managing Leisure, 13, 139-161.

Kang, G., \& James, J. (2004). Service quality dimensions: an examination of Gronroos's service quality model. Managing Service Quality: An International Journal, 14(4), 266-277.

Khare, A. (2013). Retail service quality in small retail sector: the Indian experience. Facilities, 31(5/6), 208-222. 
Kim, S., \& Jin, B. (2002). Validating the retail service quality scale for US and Korean customers of discount stores: an exploratory study. Journal of Services Marketing, 16(3), 223-237.

Kitcharoen, K. (2004). The Importance-Performance Analysis of Service Quality. ABAC Journal, 24(3), 20-46.

Kongcheep, S. (2014). Research \& Forecast Report: Bangkok Thailand Retail Q3 2014. Collier International Thailand.

Ladhari, R. (2009). Service quality, emotional satisfaction, and behavioural intentions. Managing Service Quality: An International Journal, 19(3), 308-331.

Lasorn, Y., \& Kananurak, N. (2012). The Study of Customer Behavior Satisfaction and Loyalty of Community Mall in Bangkok and Suburban Area. Marketing and Communication Journal, 1(1), 1733.

Lonial, S., Menezes, D., Tarim, M., Tatoglu, E., \& Zaim, S. (2010). An evaluation of SERVQUAL and patient loyalty in an emerging country context. Total Quality Management, 21(7), 813-827.

Markovic, S., \& Raspor, S. (2010). Measuring Perceived Service Quality Using SERVQUAL: A Case Study of the Croatian Hotel Industry. Management, 5(3), 195-209.

Mehta, C., Lalwani, K., \& Han, L. (2000). Service quality in retailing: relative efficiency of alternative measurement scales for different product-service environments. International Journal of Retail \& Distribution Management, 28(2), 62-72.

Nisco, A., \& Warnaby, G. (2013). Shopping in downtown: The effect of urban environment on service quality perception and behavioural intentions. International Journal of Retail \& Distribution Management, 41(9), 654-670.

Nunnally, C. (1978). Psychometric theory, $2^{\text {nd }}$ edition. New York, NY: McGraw Hill.

Parasuraman, A., Zeithaml, V., \& Berry, L. (1985). A Conceptual Model of Service Quality and Its Implications for Future Research. Journal of Marketing, 49(4), 41-50.

Parasuraman, A., Zeithaml, V., \& Berry, L. (1988). SERVQUAL: A Multiple-Item Scale for Measuring Consumer Perceptions of Service Quality. Journal of Retailing, 64(1), 12-40.

Parasuraman, A., Zeithaml, V., \& Berry, L. (1991). Refinement and reassessment of the SERVQUAL scale. Journal of Retailing, 67, 420-450.

Parasuraman, A., Zeithaml, V., \& Berry, L. (1994). Reassessment of expectations as a comparison standard in measuring service quality: implications for future research. Journal of Marketing, 58, 111-124.

Pitchon, J. (2015). Bangkok Retail MarketView Q4 2014. CBRE ResearchThailand.

Reimer, A., \& Kuehn, R. (2005). The impact of servicescape on quality perception. European Journal of Marketing, 39(78), 785-805.

Siu, M., \& Cheung, T. (2001). A measure of retail service quality. Marketing Intelligence and Planning, 19(2), 88-96.

Sureshchander, S., Rajendran, C., \& Anatharaman, N. (2002). The relationship between service quality and customer satisfaction: a factor specific approach. Journal of Services Marketing, 16(4), 363-379. 


\section{Author}

\section{Supeecha Panichpathom}

Associate Professor of Thammasat Business School (Thailand). The interested research areas are interdisciplinary studies pertinent to consumer behaviour in real estate business and social network contexts. PhD in Management Information Systems from University of Texas at Arlington (USA). Education background at bachelor and master's degrees are Accounting and Management Information Systems.

Correspondence to: Assoc. Prof Supeecha Panichpathom, PhD, Thammasat University, Thammasat Business School, Management Information Systems Department and Real Estate Business Program Department, 2 Prachan Road, Pranakorn, Bangkok 10200, Thailand, e-mail: supeecha@tbs.tu.ac.th

\section{Acknowledgements and Financial Disclosure}

This research study has gotten research grant from Thammasat Business School.

\section{Copyright and License}

This article is published under the terms of the Creative Commons Attribution - NonCommercial - NoDerivs (CC BY-NC-ND 3.0) License http://creativecommons.org/licenses/by-nc-nd/3.0/

Published by the Centre for Strategic and International Entrepreneurship - Krakow, Poland 